\title{
Seasonal patterns of the bacterioplankton community composition in a large mesotrophic lake
}

\author{
Walter Zwisler, Natascha Selje, Meinhard Simon* \\ Institute for Chemistry and Biology of the Marine Environment, University of Oldenburg, 26111 Oldenburg, Germany
}

\begin{abstract}
The composition of the bacterioplankton community in mesotrophic Lake Constance was studied from April 1996 to December 1997 by fluorescence in situ hybridization (FISH) with group specific oligonucleotide probes and denaturing gradient gel electrophoresis (DGGE). Between 10 and $59 \%$ of the DAPI-stained cells were detected as Bacteria with means of $38 \pm 12,27 \pm 10$ and $23 \pm 6 \%$ at 3,20 , and $50 \mathrm{~m}$ depth, respectively. In the euphotic zone at $3 \mathrm{~m}$ depth, $\beta$-Proteobacteria always constituted highest proportions of the bacterial community detected by FISH and constituted 6 to $23 \%$ of the DAPIstained cells with a mean of $12 \%$. Proportions of bacteria belonging to the Cytophaga/Flavobacteria (CF) cluster and the $\alpha$-Proteobacteria at this depth were $5.4 \pm 2.5$ and $4.1 \pm 3.5 \%$, respectively. Proportions of $\beta$-Proteobacteria decreased at 20 and $50 \mathrm{~m}$, whereas that of $\alpha$-Proteobacteria remained constant and that of the CF-cluster increased to $7.4 \%$, such that they comprised similar proportions as $\beta$-Proteobacteria at $50 \mathrm{~m}$ depth. $\gamma$-Proteobacteria were always of minor importance and constituted only $2.2 \pm 1.3 \%$ of the DAPI cell counts. Cumulative proportions of all detected bacterial groups constituted $75 \%$ of the $B$ aCteria counts at $3 \mathrm{~m}, 84 \%$ at $20 \mathrm{~m}$ and $99 \%$ at $50 \mathrm{~m}$. The DGGE analysis of the bacterioplankton community showed seasonal and vertical variations of the banding patterns even though several bands occurred throughout the study period and at all depths. A cluster analysis revealed distinct bacterial clusters of the phytoplankton spring bloom and the later period and of epilimnetic and hypolimnetic waters. The sequence analysis of the excised bands indicated that all groups which were detected by FISH were represented in the patterns. Sequence similarities of the retrieved sequences to known isolates were $<90$ to $96.1 \%$, and to other phylotypes as close as $99 \%$. Phylotypes of $\beta$-Proteobacteria and Actinobacteria of the typical banding patterns affiliated closely with recently described clusters of typical freshwater bacteria. In addition, we identified phylotypes of the Holophaga/Acidobacterium and Nitrospira phylum during the stratified period in samples from $50 \mathrm{~m}$ and during mixing from all 3 depths.
\end{abstract}

KEY WORDS: Bacteria · DGGE · Fluorescence in situ hybridization · Lake Constance $\cdot$ Actinobacteria • Nitrospira $\cdot$ Holophaga

Resale or republication not permitted without written consent of the publisher

\section{INTRODUCTION}

During the last 2 decades bacterioplankton has been identified and characterized as an integral component of pelagic ecosystems. In many studies heterotrophic bacteria have been shown to process large proportions of the organic carbon fixed by phytoplankton primary production. Depending on the trophic state and season, this proportion varies from 20 to $>60 \%$ (Cole et al. 1988, Simon et al. 1998a). An inherent presumption of all studies which focused on the cycling of organic matter by bacterioplankton is that the latter are considered as an entity or black box without any further differentiation with respect to its taxonomic composition. In order to obtain a better understanding of the growth dynamics, spatio-temporal variations and controlling factors of bacterioplankton communities, it is of great importance to elucidate their taxonomic composition as well.

During the last decade powerful molecular biological methods, based on various aspects of the analysis of nucleic acids, became available to examine the taxonomic composition of natural bacterial communities. 
The 2 approaches most widely used are rRNA-targeted fluorescence in situ hybridization (FISH; Amann et al. 1995) and denaturing gradient gel electrophoresis of PCR-amplified 16S rRNA gene fragments (DGGE) (Muyzer et al. 1998). The first approach allows a quantitative analysis of the composition of natural prokaryotic communities. Using probes of various specificity, 40 to $80 \%$ of the bacterioplankton cells in freshwater and marine environments have been detected (Glöckner et al. 1999, Šimek et al. 1999, 2001, Simon et al. 1999, Brümmer et al. 2000, Eilers et al. 2000). In freshwater systems, usually $\beta$-Proteobacteria dominate, and cells of the Cytophaga/Flavobacteria cluster also comprise high proportions, whereas in marine environments members of the Cytophaga/Flavobacteria cluster, followed by $\alpha$ - and $\gamma$-Proteobacteria, constitute largest proportions of the detectable bacterial cells. $\beta$-Proteobacteria appear to be absent in marine environments except in estuarine and coastal areas. Despite the availability of the FISH approach for more than $8 \mathrm{yr}$, surprisingly few studies on the spatio-temporal dynamics of bacterioplankton communities are available. In order to better understand their growth dynamics and controlling factors, more such studies are needed.

The DGGE approach is attractive because it allows a rapid qualitative analysis of the phylogenetic structure of bacterial communities. Its application revealed rather stable seasonal as well as pronounced temporal and spatial variations of bacterial communities in aquatic systems (Lindström 1998, 2000, Konopka et al. 1999, Lebaron et al. 1999, Hollibaugh et al. 2000, Riemann et al. 2000, Riemann \& Winding 2001). So far, spatio-temporal dynamics of pelagic bacterioplankton communities in large lakes have not been investigated by DGGE. Given the limitations of the DGGE and FISH approaches, we assume that we will obtain a much better insight into the spatio-temporal dynamics and controls of the composition of the bacterioplankton community if we apply both approaches simultaneously.

The aim of our study was to investigate the spatiotemporal dynamics of the bacterioplankton community in Lake Constance, a large mesotrophic lake, over a 2 yr period. $\beta$-Proteobacteria always constituted the largest proportion of the bacterial community as identified by FISH. The DGGE and cluster analysis further revealed that distinct bacterial clusters occurred seasonally and vertically. The sequence analysis of the 16S rRNA gene fragments revealed that in the epilimnion few $\beta$-Proteobacteria, and also Actinobacteria, with high GC content existed. Additionally, few Nitrospira- and Holophaga/Acidobacterium-related bacteria with high GC contents were detected in the hypolimnion.

\section{MATERIALS AND METHODS}

Study site and sampling. Lake Constance is a warmmonomictic mesotrophic lake adjacent to Germany, Switzerland and Austria with a total area of $472 \mathrm{~km}^{2}$. Maximum and mean depths are 253 and $101 \mathrm{~m}$, respectively. The plankton ecology of the lake has been studied extensively during the last decade (Gaedke 1998, Häse et al. 1998, Simon et al. 1998a). Samples were collected between April 1996 and December 1997 in weekly to monthly intervals at the center of Lake Überlingen, a fjord-like arm in the north-western area of the lake. The samples were transferred into opaque plastic jars and further processed in the lab within $2 \mathrm{hr}$. Temperature and chl $\mathrm{a}_{\text {, }}$ determined spectrophotometrically after hot ethanol extraction (Häse et al. 1998), were available from the data base of the special collaborative program 'Cycling of Matter in Lake Constance' (SFB-248).

Total cell abundance. Bacterial abundance was determined by epifluorescence microscopy (Porter \& Feig 1980). Duplicate subsamples of 1 to $2 \mathrm{ml}$ were stained with DAPI for $15 \mathrm{~min}$ in the dark, filtered through $0.2 \mu \mathrm{m}$ black Nuclepore filters and enumerated under a Nikon epifluorescence microscope (Labophot 2). The coefficient of variation ( $\mathrm{CV}$; standard deviation/mean) of the 20 fields of view counted was always $<0.11$.

FISH. We performed FISH with rRNA-targeted oligonucleotide probes of triplicate subsamples as described in Glöckner et al. (1996). Briefly, 3 to $5 \mathrm{ml}$ samples were filtered onto black $0.2 \mu \mathrm{m}$ Nuclepore filters, fixed for 30 min with a freshly prepared $4 \%$ paraformaldehyde solution, rinsed twice with $3 \mathrm{ml}$ of phosphate buffer saline (PBS), $\mathrm{pH} 7.2$, and kept at $4^{\circ} \mathrm{C}$ in the dark until hybridization within 3 wk. For hybridization, filters were cut into thirds and placed onto glass slides. The following oligonucleotide probes were applied to duplicates: EUB338 specific for the domain Bacteria (Amann et al. 1990), ALF1b, BET42a, GAM42a $(\alpha-, \beta$ - and $\gamma$ Proteobacteria; Manz et al. 1992) and CF319a (bacteria of the Cytophaga/Flavobacteria cluster; Manz et al. 1996). Hybridization with the oligonucleotide probes was done at $46^{\circ} \mathrm{C}$ for $90 \mathrm{~min}$ in the dark, followed by washing with PBS for $15 \mathrm{~min}$ at the same temperature. Thereafter, the samples were stained by DAPI and the bacteria enumerated by epifluorescence microscopy. The CV from counts of 10 fields of view on triplicate filter pieces was always $<0.15$.

Nucleic acid extraction and PCR amplification of 16S rRNA gene fragments. For genomic DNA extraction, bacterial biomass of 100 to 2001 from $3 \mathrm{~m}$ depth was concentrated by tangential flow filtration with a $0.1 \mu \mathrm{m}$ hollow fiber cartridge (Amicon ProFlux M 12). In samples from the depth profiles, bacterial biomass of $150 \mathrm{ml}$ samples was collected on $0.2 \mu \mathrm{m}$ Nuclepore 
filters. The biomass concentrates were stored at $-30^{\circ} \mathrm{C}$ for up to 6 mo until DNA extraction. DNA was extracted by a slightly modified standard hot phenol protocol. Therefore, the biomass was resuspended in $500 \mu \mathrm{l}$ TENP-buffer $(50 \mathrm{mM}$ TRIS, $20 \mathrm{mM}$ EDTA, $100 \mathrm{mM}$ $\mathrm{NaCl}, 2 \%$ PVPP, pH 8) (Picard et al. 1992) and $100 \mu \mathrm{l}$ of a $20 \%$ sodium dodecyl sulphate (SDS) solution. Protein was removed by a hot phenol and phenol/chloroform extraction (chloroform $=$ chloroform/isoamylalcohol: 24/1). After DNA precipitation with isopropanol, the nucleic acid was redissolved in $50 \mu \mathrm{l}$ Tris-ethylenediaminetetraacetic acid (TE)-buffer $(10 \mathrm{mM}$ Tris- $\mathrm{HCl}$, 1 mM EDTA, pH 8.0) and stored at $4^{\circ} \mathrm{C}$.

PCR was performed in $50 \mu$ lassays with a GENIUS thermal cycler (Techne). 16S rRNA gene fragments were amplified using the primer set 341F (5'-GC-clamp-CCT ACG GGA GGC AGC AG-3'; GC-clamp: 5'-CGC CCG CCG CGC CCC GCG CCC GTC CCG CCG CCC CCG CCC G-3') and 907Re (5'-CCG TCA ATT C[A/C]T TTG AGT TT-3'; Wawer et al. 1997, Muyzer et al. 1998). All PCRs were conducted with 1 to $2 \mu \mathrm{l}$ of DNA template solution (10 to $30 \mathrm{ng}$ DNA) in buffer supplied by the Taq polymerase manufacturer (Pharmacia). The final volume of $50 \mu \mathrm{l}$ contained $200 \mu \mathrm{M}$ of the dNTP-mixture (Pharmacia), $0.5 \mu \mathrm{M}$ of each primer and 2 units of Taq polymerase in double distilled $\mathrm{H}_{2} \mathrm{O}$. After an initial denaturing step $\left(2 \mathrm{~min}, 94^{\circ} \mathrm{C}\right)$ a 'touchdown' PCR (Don et al. 1991) was performed in which the annealing temperature was set to $65^{\circ} \mathrm{C}(50 \mathrm{~s})$ and decreased $0.5^{\circ} \mathrm{C}$ every cycle until $55^{\circ} \mathrm{C}$ was reached $(20$ cycles) and 12 more cycles were carried out. The polymerization step was performed at $72^{\circ} \mathrm{C}$ for $2 \mathrm{~min}$. PCR products were examined by standard agarose gel electrophoresis $(1 \%$ agarose, $1 \times$ TAE buffer $[40 \mathrm{mM}$ Tris base, $20 \mathrm{mM}$ glacial acetic acid, $1 \mathrm{mM}$ EDTA]). DNA was visualized by ethidium bromide fluorescence.

DGGE. PCR products were analyzed by DGGE with a DCode $^{\mathrm{TM}}$ System (BioRad) as described elsewhere (Muyzer et al. 1996, Teske et al. 1996). DGGE was performed in a $6 \%$ (wt/vol) polyacrylamide gel with a denaturing gradient from 20 to $50 \%$ denaturants $(100 \%$ means $7 \mathrm{M}$ urea and $40 \%$ [vol/vol] formamide). Twenty $\mu$ l of the PCR products (600 ng DNA) were loaded on each lane of the gel. On each gel the PCR product of a bacterial isolate from Lake Constance (Ub41) was used as a standard. After electrophoresis for $5 \mathrm{~h}$ at constant $200 \mathrm{~V}$ and a temperature of $60^{\circ} \mathrm{C}$, gels were stained either with ethidium bromide $\left(0.5 \mathrm{mg} \mathrm{l}^{-1}\right.$; $20 \mathrm{~min})$ or $\mathrm{SYBR}^{\circledR}$ Gold $\left(0.1 \mu \mathrm{ml}^{-1} ; 40 \mathrm{~min}\right.$; Molecular Probes) and photographed on a UV transilluminator with a black and white Polaroid Camera. Several series of parallel gels stained by both dyes yielded consistently similar banding patterns of equal intensity.

A cluster analysis of the DGGE banding patterns was performed using the software GelCompare II, Version
2.5 (Applied Maths, St. Martens-Latem, Belgium). We applied 5 to $20 \%$ background subtraction depending on the signal-to-noise ratio of the corresponding gel. Patterns were compared curve-based using Pearson correlation as similarity coefficient and UPGMA (unpaired group method of analysis) to generate the dendrogram. We used the position tolerance optimization option of the software to fit the curves to the best possible matching. From the given cophenetic correlation values and the similarity values for the internal standards, the most likely result was chosen.

For sequence analyses pieces of selected DGGE bands were cut out of the gel and stored for $48 \mathrm{~h}$ at $4^{\circ} \mathrm{C}$ in $50 \mu \mathrm{l}$ of ultrapure water (K-persulfate-oxidized Milli-Q water). After centrifugation $(1 \mathrm{~min}, 8000 \times g)$, $1 \mu \mathrm{l}$ of the supernatant was used for another PCR amplification as described above. Because this second-step PCR product was used for cloning or direct sequencing, the 341F primer had no GC-clamp on its 5'-end.

Cloning and sequencing. For the sequence analysis, DNA of a single phylotype is necessary. To ensure this the PCR products of the excised bands were cloned with the PCR-Script ${ }^{\mathrm{TM}}$ Amp Cloning Kit (Stratagene) into Epicurian Coli ${ }^{\circledR}$ XL1-Blue MRF'Kann supercompenent cells. The amplified plasmid was purified with the ClearCut ${ }^{\mathrm{TM}}$ Miniprep Kit (Stratagene). All steps in these procedures followed the instruction manuals of the manufacturer.

Sequence reactions were performed by the professional sequencing company GATC Biotech AG. Sequence analysis was done with the software package ARB (Strunk et al. 1998). The phylogenetic analysis was performed with the ARB software package (available at www.arb-home.de; Strunk et al. 1998). An unrooted tree was constructed using parsimony, neighbor-joining, and maximum-likelihood analysis. The backbone tree calculated using maximumlikelihood analysis and almost full length 16S rRNA gene sequences (>1300 bp). A total of 148 sequences from different families, as suggested in the prokaryotic representative listing in the Ribo-somal Database Project II (RDP 2000, available at http://rdp.cme. msu.edu/html/), and sequences of closest relatives as found by BLAST search, were used for the backbone tree. A filter was constructed for every phylogenetic group in focus of the analysis. Hence, alignment positions, at which less than $50 \%$ of sequences of the corresponding data set had the same residues, were excluded from the calculations to prevent uncertain alignments within highly variable positions. Shorter sequences and sequences of the DGGE bands were added afterwards by maximum parsimony using the same filter. Sequences are available at GenBank under the accession numbers AF337192-AF337214 (see Table 2). 


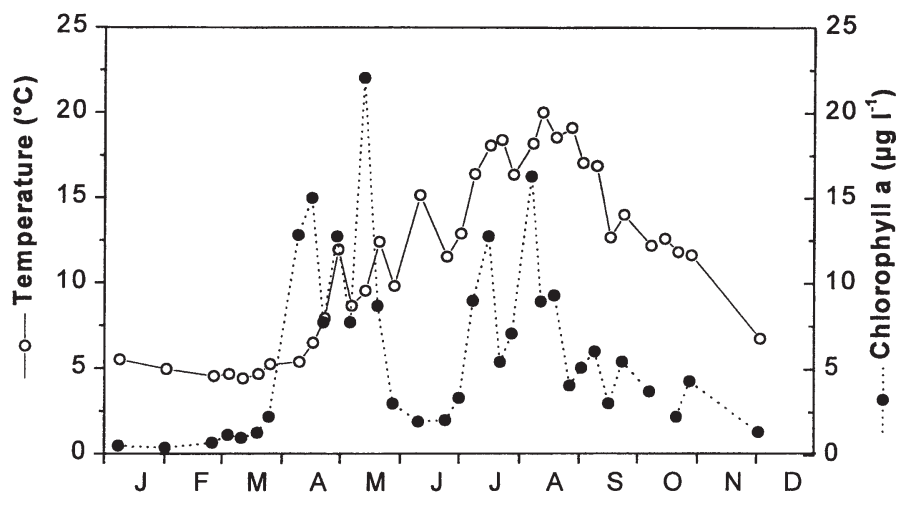

Fig. 1. Temperature at $5 \mathrm{~m}$ depth and chl a concentrations at $3 \mathrm{~m}$ depth in Lake Constance between January and December 1996

\section{RESULTS}

In 1996, the temperature started to increase in April and reached more than $15^{\circ} \mathrm{C}$ in July such that the lake became thermally stratified. Highest temperatures of around $20^{\circ} \mathrm{C}$ occurred in August. Thereafter, the lake continuously cooled down and reached $6^{\circ} \mathrm{C}$ in December (Fig. 1). In 1997, the onset of the warming started 3 wk later but proceeded rather similarly to the previous year. The thermal stratification persisted longer in late summer and fall such that in December the lake was still warmer than $8^{\circ} \mathrm{C}$ in the upper $30 \mathrm{~m}$.

The phytoplankton spring bloom in 1996 developed between mid-April and mid-May and reached chl a concentrations of $22.4 \mu^{-1} \mathrm{l}^{-1}$ (Fig. 1). It was terminated by heavy grazing of daphnids and followed by the clear water-phase in June. In July and August, 2 further phytoplankton blooms were recorded. In the following year, the spring bloom developed $3 \mathrm{wk}$ later and its peak reached only $50 \%$ of the chl a concentration recorded in 1996 (data not shown). In summer, chl a concentrations remained lower than in the previous year and

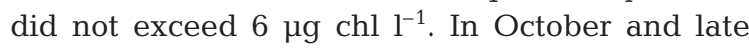
November, however, 2 further phytoplankton blooms occurred.

\section{Bacteria and FISH}

In 1996, total bacterial numbers varied between 1.6 and $6.1 \times 10^{6} \mathrm{ml}^{-1}$ at $3 \mathrm{~m}$ (Fig. 2A). Highest numbers were reached at the first chlorophyll peak of the spring bloom in the second half of April. Further peaks occurred at the end of the spring bloom during the clear-water phase and in late August. In 1997, the seasonal patterns of the bacterial numbers at $3 \mathrm{~m}$, ranging between 1.4 and $6.0 \times 10^{6} \mathrm{ml}^{-1}$, were basically similar to those in 1996 (data not shown).

Cells of the domain Bacteria detected by probe EUB338 ranged from 0.5 to $2.6 \times 10^{6} \mathrm{ml}^{-1}$, and accounted for $40.3 \%$ of the DAPI counts in 1996, and $34.6 \%$ in 1997, at $3 \mathrm{~m}$ as an annual mean (Table 1). Both percentages were not significantly different from each other ( $U$-test, $\mathrm{p}<0.01$ ). Highest fractions constituted 59.3 and $55.4 \%$ of the DAPI cell counts in both years, respectively (Table 1). There was no systematic covariation of the fraction of Bacteria detected by EUB338 with bacterial numbers, chlorophyll concentrations or temperature. $\beta$-Proteobacteria constituted highest numbers and proportions of all bacteria detected at $3 \mathrm{~m}$ and comprised 11 to $13 \%$ of the DAPI cell counts in both years, equivalent to $35 \%$ of the Bacteria counts (Fig. 2D, Table 1). Maxima and minima during the spring bloom, the clear-water phase, and in summer often covaried with those of the DAPI cell counts. The linear regression analysis between the DAPI cell counts and EUB cell counts in 1996 and 1997 yielded an $r^{2}$ of $0.51(n=22, p<0.05)$ and of $0.98(n=$
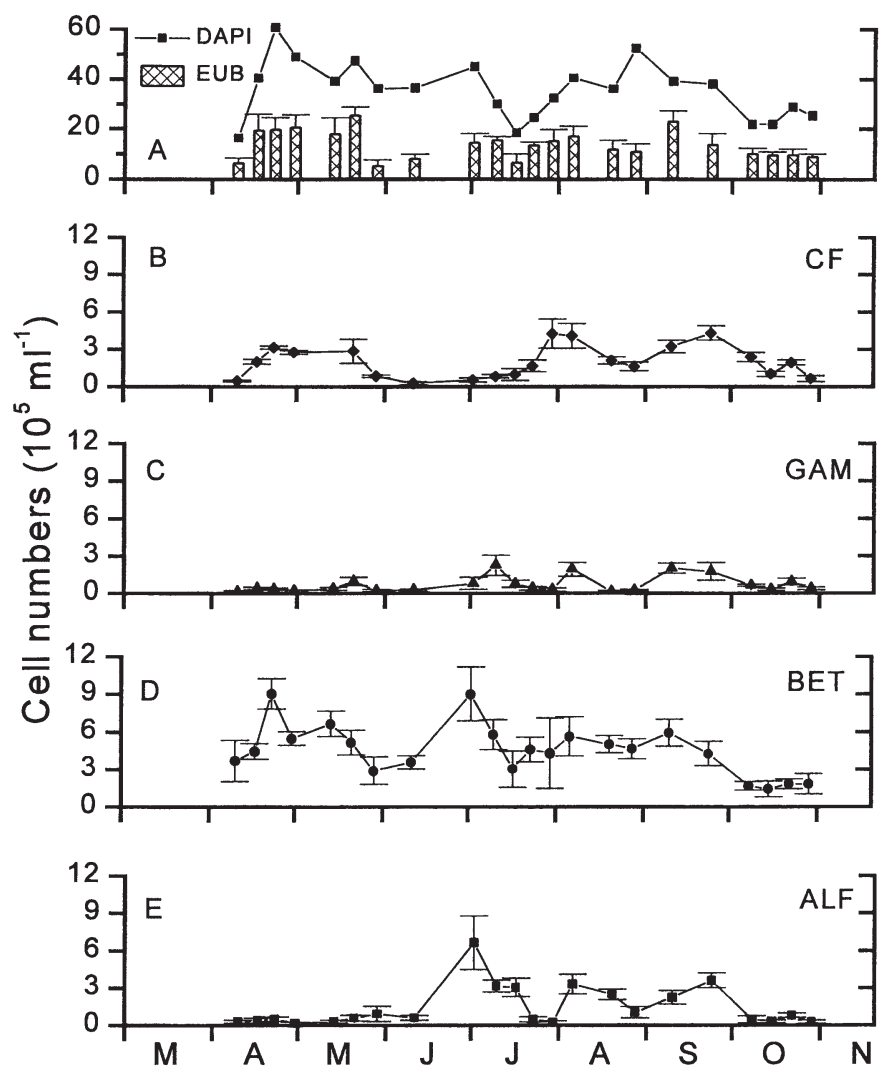

Fig. 2. Bacterioplankton numbers at $3 \mathrm{~m}$ depth in Lake Constance between April and November 1996. (A) Numbers of DAPIstainable cells and Bacteria (EUB), (B) Cytophaga/Flavobacteria (CF), (C) $\gamma$-Proteobacteria (GAM), (D) $\beta$-Proteobacteria (BET), (E) $\alpha$-Proteobacteria (ALF) 
Table 1. Annual means \pm SD and range of Bacteria, $\alpha-, \beta$ - and $\gamma$-Proteobacteria and Cytophaga/Flavobacteria as percent of DAPIstainable cells and \% Bacteria for 1996 and 1997 at $3 \mathrm{~m}$ depth in Lake Constance

\begin{tabular}{|c|c|c|c|c|c|c|c|c|}
\hline & \multicolumn{4}{|c|}{1996} & \multicolumn{4}{|c|}{-1997} \\
\hline & \multicolumn{2}{|c|}{ Mean } & \multicolumn{2}{|c|}{ Range } & \multicolumn{2}{|c|}{ Mean } & \multicolumn{2}{|c|}{ Range } \\
\hline & $\%$ DAPI & \% Bacteria & $\%$ DAPI & $\%$ Bacteria & $\%$ DAPI & $\%$ Bacteria & \% DAPI & $\%$ Bacteria \\
\hline Bacteria & $40.3 \pm 11.4$ & - & $15.5-59.3$ & - & $34.6 \pm 12.9$ & - & $10.1-55.4$ & - \\
\hline$\alpha$-Proteobacteria & $4.3 \pm 4.6$ & $11.6 \pm 12.7$ & $3.6-16.6$ & $0.8-44.7$ & $3.9 \pm 2.5$ & $12.5 \pm 6.9$ & $3.6-16.6$ & $0.8-44.7$ \\
\hline$\beta$-Proteobacteria & $12.8 \pm 4.7$ & $33.8 \pm 12.8$ & $6.3-22.5$ & $14.6-60.8$ & $11.2 \pm 3.8$ & $34.9 \pm 7.6$ & $3.3-16.2$ & $23.1-46.0$ \\
\hline$\gamma$-Proteobacteria & $2.6 \pm 1.9$ & $6.7 \pm 5.6$ & $0.4-7.5$ & $1.0-23.8$ & $1.8 \pm 0.7$ & $6.2 \pm 3.1$ & $0.9-3.4$ & $2.8-12.9$ \\
\hline Cytophaga/Flavobacteria & $5.7 \pm 3.3$ & $14.2 \pm 7.2$ & $0.7-13.1$ & $3.4-30.8$ & $5.1 \pm 1.8$ & $18.9 \pm 11.3$ & $3.4-8.4$ & $7.1-42.4$ \\
\hline
\end{tabular}

$10, \mathrm{p}<0.05)$, respectively. On some occasions, such as during the early spring bloom and in early July, $\beta$-Proteobacteria accounted for as much as 55 to $60 \%$ of the EUB counts. Cells of the Cytophaga/Flavobacteria cluster constituted between 4.3 and $8.7 \%$ of the DAPI cell counts at $3 \mathrm{~m}$ except during the clear-water phase when they reached only 1 to $3 \%$ (Fig. 2B). Between the end of October 1996 and March 1997 and in December 1997 they reached between 19 and $42 \%$ of the Bacteria counts and constituted proportions nearly as high as those of $\beta$-Proteobacteria. As an annual mean, Cytophaga/Flavobacteria constituted 5.7 and $5.1 \%$ of the DAPI cell counts in 1996 and 1997, respectively, which is equivalent to 14.2 and $18.9 \%$ of the Bacteria counts (Table 1$)$. $\alpha$-Proteobacteria only reached substantial proportions of the bacterioplankton community after the clear-water phase from July until September. Except for a short time during this period, they constituted 7 to $16 \%$ of the DAPI cell counts, equivalent to 20 to $40 \%$ of the Bacteria counts, with a mean of $6.7 \%$ (Fig. 2E). They were the second most abundant bacterial phylogenetic group during this period. As an annual mean $\alpha$-Proteobacteria comprised around $4 \%$ of the DAPI cell counts and $12 \%$ of the Bacteria counts (Table 1). $\gamma$-Proteobacteria comprised always lowest proportions of all bacteria detected without any systematic patterns.

In May, August, October, November and December 1997 we also analyzed the community structure of the bacterioplankton by FISH at 20 and $50 \mathrm{~m}$. DAPI cell counts systematically decreased with depth and reached around $1 \times 10^{6}$ cells $\mathrm{ml}^{-1}$ at $50 \mathrm{~m}$. Accordingly, absolute numbers of bacteria detected by the Bacteria probe and group specific probes decreased with depth as well. Proportions of DAPI cell counts detected by the EUB-probe at 20 and $50 \mathrm{~m}$ were only 27 and $23 \%$, respectively (Fig. 3). Relative proportions of $\beta$ - and $\gamma$-Proteobacteria did not change vertically. The proportions of $\alpha$-Proteobacteria, however, significantly increased at 20 and $50 \mathrm{~m}$ as compared to $3 \mathrm{~m}$ and reached $22 \%$ of the Bacteria counts. Cells of the Cytophaga/Flavobacteria cluster constituted signifi- cantly higher proportions of Bacteria counts at $50 \mathrm{~m}$ as compared to 3 and $20 \mathrm{~m}$ and reached $32 \%$, the same proportion as $\beta$-Proteobacteria. The cumulative fraction of bacteria detected by the group-specific probes increased with depth and reached $99 \%$ of the EUB counts at $50 \mathrm{~m}$ (Fig. 3).
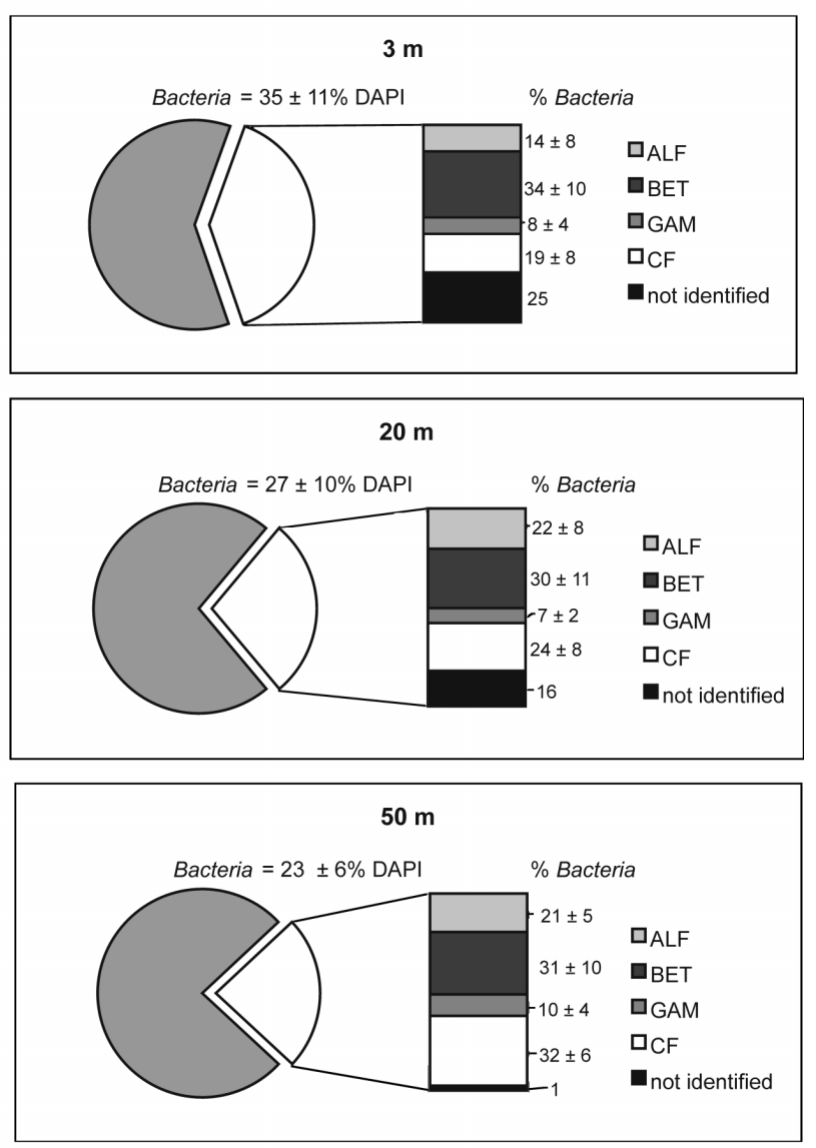

Fig. 3. Proportions of Bacteria (\% DAPI cell counts) and of $\alpha$ - (ALF), $\beta$ - (BET) and $\gamma$-Proteobacteria (GAM) and of Cytophaga/Flavobacteria (CF) at 3, 20 and $50 \mathrm{~m}$ depth in Lake Constance ( $\%$ Bacteria). Mean values $\pm \mathrm{SE}$ from samples taken on 21 May, 26 August, 7 October, 4 November and 17 December 1997 are given. Percentage of Bacteria not detected by any of the probes applied is also given (not identified) 
Pearson correlation $\begin{array}{llllll}0 & 20 & 40 & 60 & 80 & 100\end{array}$
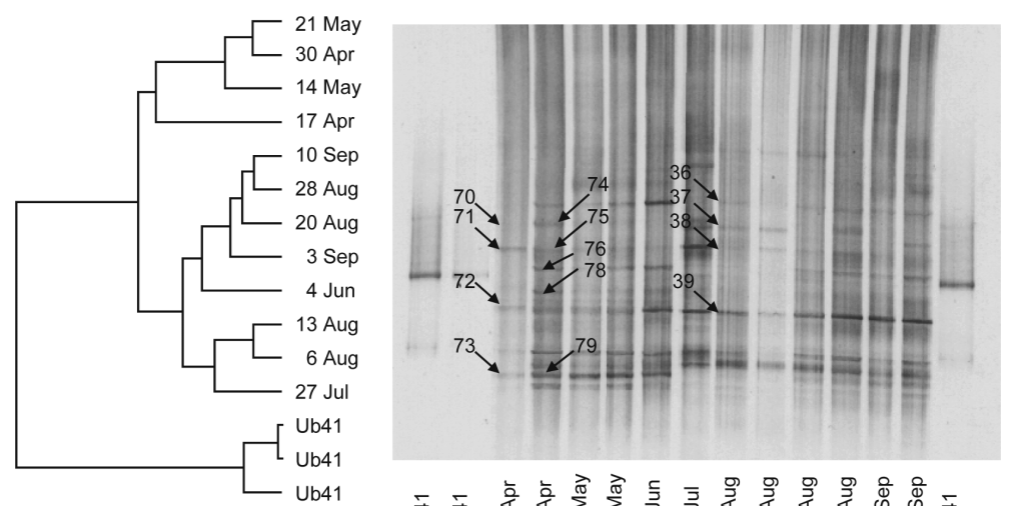

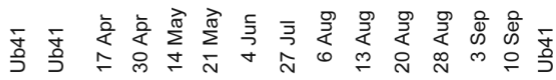

Fig. 4. Inverted DGGE gel stained with $\mathrm{SYBR}^{\circledR}$-Gold of PCR-amplified $16 \mathrm{~S}$ rRNA gene fragments from samples collected at $3 \mathrm{~m}$ depth in Lake Constance between 17 April and 10 September 1996. Numbers denote bands which were excised for sequence analysis and phylogenetic affiliation. Numbers of the bands refer to the numbering of the LCo clones. Ub41: reference strain

\section{DGGE banding patterns and sequence analysis}

The DGGE banding patterns of the $3 \mathrm{~m}$ samples showed seasonal variations but the majority of the bands occurred throughout the study period, such as Band 72 (Fig. 4). Ten to 15 bands were detected on each lane. The cluster analysis identified 2 major clusters, 1 of the phytoplankton spring bloom (17 April to 21 May), and 1 of the following period including the clear-water phase in June and summer until September. The cluster of the latter period is further subdivided into 1 subcluster including the clear-water phase in June and the period of late August until September at rather low chl a concentrations, and 1 including the period from late July until mid-August when the second chl a summer peak occurred.

A DGGE analysis was also conducted with samples from depth profiles between August and December 1997 (Fig. 5). The banding patterns of the 3 and $20 \mathrm{~m}$ samples of any given date were rather similar. In the $50 \mathrm{~m}$ samples, however, another prominent band occurred (Bands 18 and 23, Fig. 5). This band was also detected at 3 and $20 \mathrm{~m}$ depth in December. The cluster analysis showed that the 3 and $20 \mathrm{~m}$ sample of any given date clustered closely together and that 2 major clusters existed. One included all samples from 3 and $20 \mathrm{~m}$ depth and that of $50 \mathrm{~m}$ of October. The 3 and $20 \mathrm{~m}$ samples of December and the $50 \mathrm{~m}$ sample of October formed a separate subcluster. The second cluster included the other $50 \mathrm{~m}$ samples.

The 16S rRNA gene fragments of the most prominent bands of the $3 \mathrm{~m}$ samples from various samples were cloned and sequenced (Clones LCo36 to 39, LCo70 to 76, LCo78 to 79, Fig. 4). Numbers of the bands are identical to the numbers of the LCo clones. The sequence analysis revealed that at least 9 different phylotypes were represented by these bands (Table 2, Fig. 6). Surprisingly, only 2 sequences originated from phylotypes of $\beta$-Proteobacteria, Acidovorax sp. and Polynucleobacter necessarius being the closest related isolates with sequence similarities of 96.0 and $96.7 \%$. These phylotypes were even closer related to others from various freshwater lakes with sequence similarities of 96.7 to $99.3 \%$ of the betaII cluster of Glöckner et al. (2000). One phylotype of $\alpha$-Proteobacteria was retrieved which was related most closely to Sphingomonas sp. The 5 phylotypes associated to the Cytophaga/Flavobacteria cluster were related to Cyclobacterium marinus and Flectobacillus sp., but with sequence similarities of $<93 \%$. These phylotypes showed rather close sequence similarities with others, in particular from a lake in the Adirondack Mountains, USA (Hiorns et al. 1997) and within the cfIII-cluster of Glöckner et al. (2000). From the bands migrating

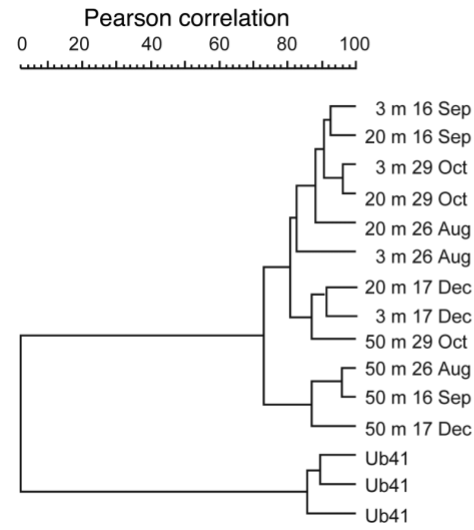

Fig. 5. Inverted DGGE gel stained with ethydium bromide of PCR-amplified 16S rRNA gene fragments from samples collected at 3, 20 and $50 \mathrm{~m}$ depth in Lake Constance on 26 August, 16 September, 29 October and 17 December 1997. Numbers denote bands which were excised for sequence analysis and phylogenetic affiliation. Numbers of the bands refer to the numbering of the LCo clones. Ub41: reference strain 


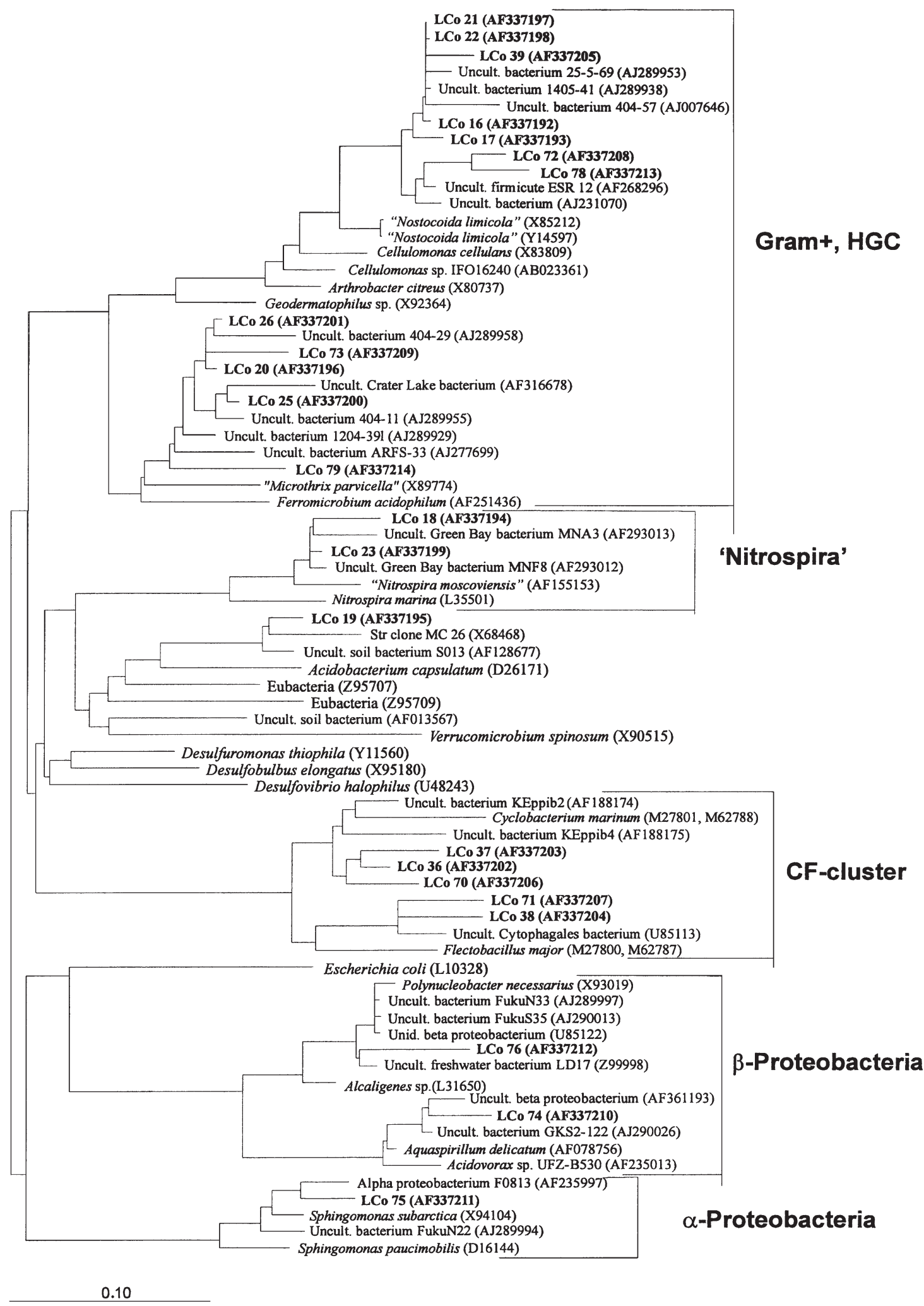

Fig. 6. Rooted phylogenetic tree of the sequenced phylotypes retrieved from the PCR-amplified 16S rRNA gene fragments of the DGGE analysis from Lake Constance and their next related isolates and phylotypes. A backbone tree based on maximum likelihood analysis was constructed with almost complete (>1300 nucleotides) sequences. Alignment positions at which less then $50 \%$ of the corresponding sequences had the same base pairs were excluded. Sequences shorter than 1300 nucleotides were added with maximum parsimony using the same filter. The scale bar indicates $10 \%$ estimated sequence divergence 


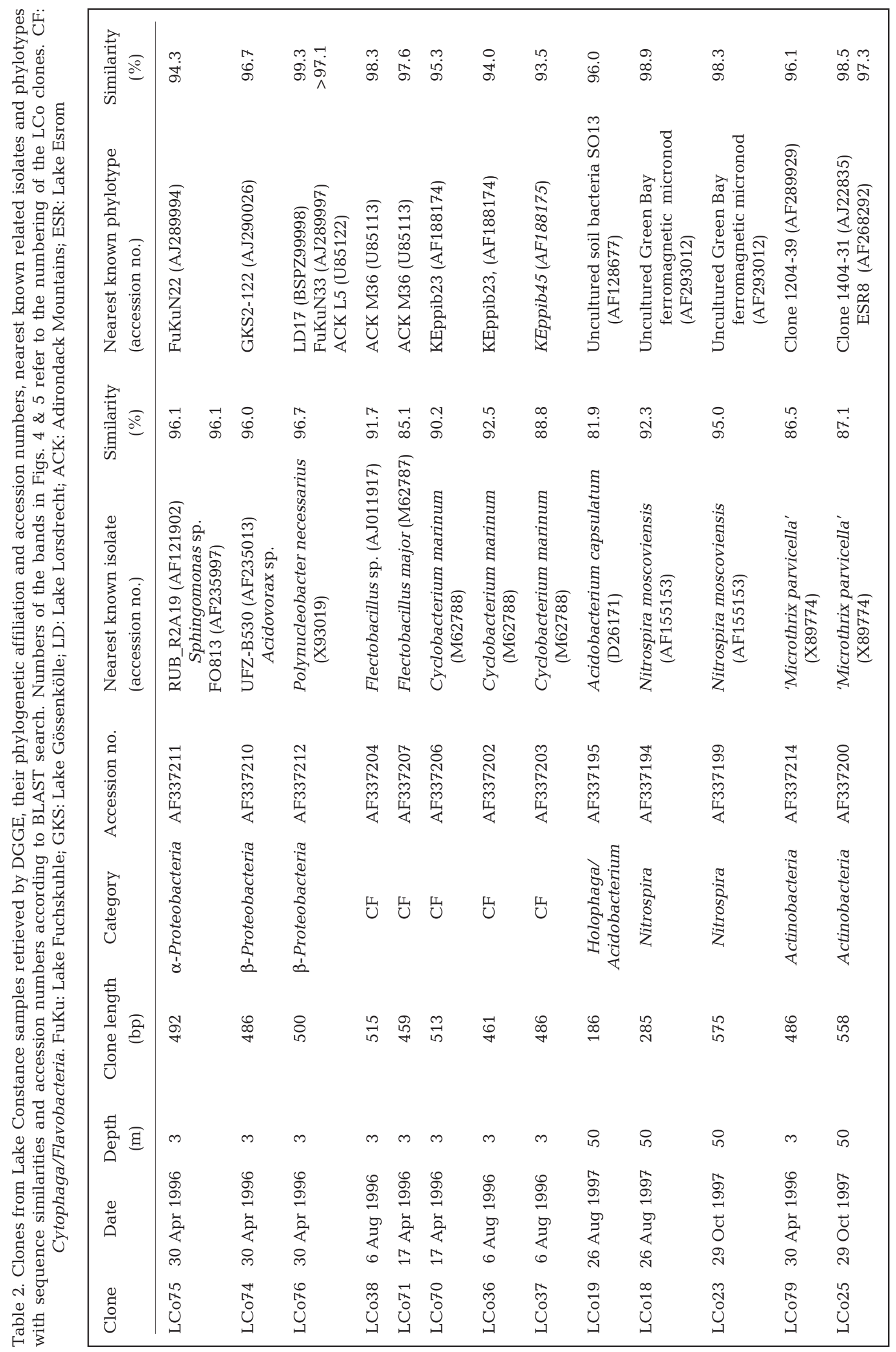




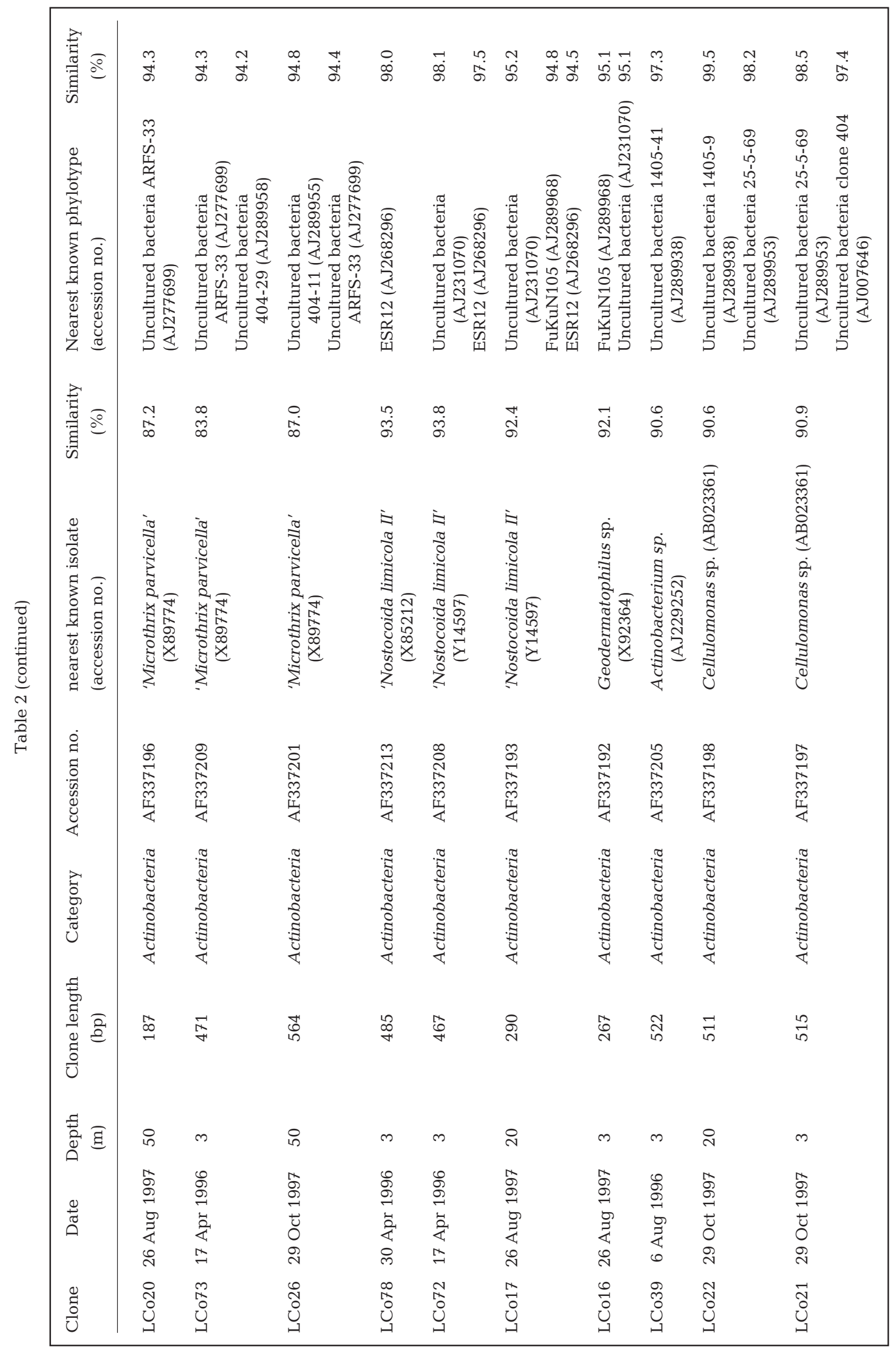


farthest in the gels, 5 phylotypes of the high GC Actinobacteria were retrieved which clustered with Cellulomonas sp./'Nostocoida limicola II' and 'Microthrix parvicella' (Table 2, Fig. 6) and within the cluster hgcI of Glöckner et al. (2000). Phylotypes LCo71, LCo75 and LCo38 migrated in the gel in a similary way, but belonged to 2 completely different phylogenetic lineages, LCo75 to $\alpha$-Proteobacteria and the others to Cytophaga/Flavobacteria (Fig. 6, Table 2). The same was true for phylotype LCo74, belonging to $\beta$-Proteobacteria and phylotypes LCo70 and LCo37, which were identified as Cytophaga/Flavobacteria. These results show that the structure of the bacterioplankton community was not as stable as inferred from the DGGE banding patterns and included bacteria not detected by the group-specific probes applied.

We also sequenced 16S rRNA gene fragments of 10 bands of the depth profiles (bands and clones LCo16 to 23, LCo25 and 26, Table 2, Fig. 6). The bands occurring only at $50 \mathrm{~m}$ between August and October were identified as representing phylotypes of the Nitrospira group (LCo18 and 23) and the Holophaga/ Acidobacterium group (LCo19). The other bands represented phylotypes of Actinobacteria from the 2 groups mentioned above.

\section{DISCUSSION}

In surface waters at $3 \mathrm{~m}$ depth, roughly $40 \%$ of the DAPI-stainable cells were detected as Bacteria by probe EUB338, but at 20 and $50 \mathrm{~m}$ depth only 27 and $23 \%$ were Bacteria. At 3 and $20 \mathrm{~m}$ at least $75 \%$ of the Bacteria were identified as members of $\alpha-, \beta$ - and $\gamma$ Proteobacteria and the Cytophaga/Flavobacteria cluster, and at 50 m even $>95 \%$, indicating that a substantial fraction of the bacterioplankton community could be characterized with the group-specific phylogenetic probes applied. Detecting cells by FISH depends on the amount of ribosomes per cell, the accessibility of the target molecule, and the fluorescence signal (Amann et al. 1995). The amount of ribosomes per cell is a positive function of the bacterial growth rate (Kemp et al. 1993), and thus an important constraint of detecting microbes by FISH in oligotrophic natural environments (Alfreider et al. 1996). The accessibility of the target molecule depends largely on the fixation of the cells and is usually done by a $4 \%$ paraformaldehyde solution for Gram-negative bacteria. The fluorescence signal has been continuously improved by applying more intensive fluorescence dyes (Southwick et al. 1990, Kenzaka et al. 1998) and polyribonucleotide probes (DeLong et al. 1999) or helper probes (Fuchs et al. 2000, Glöckner et al. 2000). The application of polyribonucleotide and helper probes signifi- cantly improved the probe signal such that the great majority of the DAPI-stainable planktonic bacteria could be detected. In fact, applying probes and helper probes specific for cluster hgcI of the Actinobacteria, Glöckner et al. (2000) demonstrated that bacteria of this cluster are important members of the bacterioplankton in freshwater lakes constituting 25 to $50 \%$ of the DAPI-stainable cells. Bacteria of this cluster were not yet detected by more traditional probes and neglected so far in FISH studies. Taking them into account rises the total fraction of DAPI-stainable bacteria in lakes to $>95 \%$ (Glöckner et al. 2000). We used the paraformaldehyde fixation procedure and CY3 as one of the most intense fluorochromes, and thus procedures widely applied. Therefore, and because we did not apply the helper probe-mix for the hgcI cluster of the Actinobacteria, it is not surprising that our detection rate by the EUB probe is at the lower end of the range found in other studies carried out in lacustrine environments applying similar types of probes (Pernthaler et al. 1998, Glöckner et al. 1999, Jürgens et al. 1999, Šimek et al. 1999, 2001). It is comparable to the detection rate of a study in the North Sea (Eilers et al. 2000) but lower than that of a study in the Southern Ocean (Simon et al. 1999). It is also lower than detection rates of bacteria associated with natural organic aggregates, activated sludge flocs or in river biofilms (Wagner et al. 1993, Grossart \& Simon 1998, Manz et al. 1999, Brümmer et al. 2000, Schweitzer et al. 2001, Simon et al. 2002). Bacteria in these habitats are bigger than free-living cells and contain more ribosomes. The lower fraction of cells detected in our study at 20 and $50 \mathrm{~m}$ are presumably due to the lower growth rates and thus lower numbers of ribosomes as compared to $3 \mathrm{~m}$ depth (Simon et al. 1998b).

Proportions of the various bacterial groups exhibited relatively low fluctuations even though pronounced spatio-temporal fluctuations in absolute cell numbers occurred. An important question concerns possible controlling factors explaining the spatio-temporal dynamics of the bacterioplankton community. These factors include substrate availability, hydrolysis and uptake, growth properties and temperature adaptation, phage infection and grazing. We made extensive statistical analyses of the temporal dynamics of the bacterioplankton groups detected by FISH with that of temperature, chl a, phytoplankton biomass, bacterial biomass production, and concentration and uptake of monosaccharides, which were measured simultaneously (Simon et al. 1998a, Bunte \& Simon 1999). None of these parameters showed significant correlations to dynamics of either of the bacterial groups, emphasizing the fact the group specific probes target rather broad and physiologically non-homogenous bacterial groups. 
$\beta$-Proteobacteria were the most abundant bacterial group identified by FISH in Lake Constance during the growing season, and were closely correlated to the DAPI cell counts. This notion is consistent with comparable studies in other freshwater systems including lakes, microscopic and macroscopic limnetic aggregates, and river biofilms (Grossart \& Simon 1998, Pernthaler et al. 1998, Glöckner et al. 1999, Šimek et al. 1999, 2001, Brümmer et al. 2000, Brachvogel et al. 2001, Schweitzer et al. 2001). Despite their great significance, limited information is available on the relative distribution of specific populations of $\beta$-Proteobacteria in lacustrine environments. In a high mountain lake, 2 probes targeting narrow clusters related to Rhodoferax fermentans and Alcaligenes sp. detected between $<10$ and $>50 \%$ of all $\beta$-Proteobacteria, with an annual mean of $25 \%$ (Pernthaler et al. 1998). In line with these findings, Šimek et al. (2001) found that $\beta$-Proteobacteria of a narrow cluster, also related to Rhodoferax fermentans and targeted with a single probe, constituted the single most abundant bacterial group in a grazer-free mesocosm. In a small eutrophic lake, a narrow cluster of $\beta$-Proteobacteria including Comamonas acidovorans, C. testosteroni, Acidovorax temperans, and A. facilis comprised proportions of 5 to $70 \%$ of the bacterioplankton community annually (Höfle et al. 1999). Bacterial communities on lake snow aggregates are also largely dominated by $\beta$-Proteobacteria and consist of relatively few members as well. Schweitzer et al. (2001), applying 3 probes of narrow clusters related to Duganella zoogloeoides (formerly Zoogloea ramigera), Hydrogenophaga sp. and A. facilis, detected between 40 and $60 \%$ of all $\beta$-Proteobacteria on lake snow aggregates in Lake Constance. The abundance of these species in the free-living bacterioplankton community, however, was below the detection limit (W. Zwisler \& M. Simon unpubl. data). It is interesting, though still puzzling, that $\beta$-Proteobacteria of a rather limited phylogenetic diversity are such a dominating group of the heterotrophic freshwater bacterioplankton. Obviously, they share common genetic properties which are advantageous for striving in such ecosystems. So far, no such traits specific to $\beta$-Proteobacteria are known which would explain their high abundance.

Cytophaga/Flavobacteria were the second most abundant bacterioplankton group identified by FISH in Lake Constance, with highest abundances under conditions when polymeric substrates and recalcitrant polymeric substrates were dominant such as during phytoplankton blooms and in deeper water layers and during winter. Labile organic substrates such as amino acids, proteins and carbohydrates are primarily produced in the course of phytoplankton blooms during the growing season in euphotic water layers, and exhibit much lower concentrations in aphotic water layers and during winter (Simon 1998, Bunte \& Simon 1999, Rosenstock \& Simon 2001). Cytophaga/Flavobacteria are known to degrade polymeric substrates of labile and rather recalcitrant nature and to comprise many meso- and psychrophilic species (Reichenbach 1992). Hence, these notions are consistent with the spatio-temporal distribution of Cytophaga/Flavobacteria found in the present study. Cytophaga/Flavobacteria have also been identified as important members of bacterial communities in other aquatic environments including lakes, rivers, and marine systems (Pernthaler et al. 1998, Šimek et al. 1999, Simon et al. 1999, Brümmer et al. 2000, Cottrell \& Kirchman 2000). In river biofilms, they constituted highest proportions during winter (Brümmer et al. 2000). Šimek et al. $(1999,2001)$ reported that under enhanced protozoan grazing pressure, Cytophaga/Flavobacteria dominated the grazing-resistant bacterial filaments.

$\alpha$-Proteobacteria constituted substantial proportions between July and September and occasionally were the second most important bacterial group during this period. Even though the proportion of this group relatively increased at 20 and $50 \mathrm{~m}$ depth as compared to $3 \mathrm{~m}$, its proportion always remained lower than that of $\beta$-Proteobacteria and Cytophaga/Flavobacteria. As the probe Alf1b also matches some Nitrospira sequences, we cannot rule out the possibility that this probe also detected Nitrospira-related cells at 20 and $50 \mathrm{~m}$ where we detected sequences of this phylotype. There is very limited information available on the occurrence of this subclass of Proteobacteria, making it difficult to explain their growth patterns. In a mesocosm study examining grazing effects of protozoans and daphnids on the structure of limnetic bacterioplankton, Jürgens et al. (1999) reported that $\alpha$-Proteobacteria constituted enhanced proportions when daphnids were absent and protozoan grazing was high. Similar observations, but not as clear-cut, were made by Šimek et al. (1999) examining size-fractionated grazing on bacterioplankton in a eutrophic reservoir. Schweitzer et al. (2001) and Knoll et al. (2001) experimentally examined the temporal succession of $\alpha$ - and $\beta$-Proteobacteria on lake snow aggregates and precursor microaggregates in Lake Constance, and found within the initial days high, but thereafter decreasing, proportions of $\alpha$-Proteobacteria. On natural microaggregates in this lake, $\alpha$-Proteobacteria were absent, supporting the idea that microaggregates represent particulate organic matter depleted greatly of labile organic matter (Brachvogel et al. 2001). Hence, there is some evidence that limnetic $\alpha$-Proteobacteria comprise bacteria which prefer rather labile organic matter, although more studies need be carried out to shed more light on the specific properties of members of this subclass of Proteobacteria. 
The DGGE and sequence analyses showed that the major phylogenetic groups detected by FISH consisted of a limited number of bacteria and phylotypes. In addition, phylotypes of 3 other phylogenetic groups not targeted by FISH were detected. The cluster analysis indicated that distinct bacterial communities existed in the epi- and hypolimnion and during the major seasonal phases such as the spring bloom and the summer period. These phases were also characterized by enhanced cell numbers of $\beta$-Proteobacteria and Cytophaga/Flavobacteria. Hence, the DGGE banding patterns, the cluster analysis and the sequencing results complement the FISH data with the group specific probes, also by revealing dominant phylotypes of the various groups detected by FISH.

Mesocosm studies with nutrient additions and different grazing impacts experimentally demonstrated that changes in substrate supply and grazing can lead to substantial changes in the bacterial community composition (Lebaron et al. 1999, van Hannen et al. 1999, Riemann et al. 2000, Riemann \& Winding 2001). Substrate supply and grazing impact exhibit pronounced changes seasonally in Lake Constance (Simon et al. 1998a, Bunte \& Simon 1999, Rosenstock \& Simon 2001), which obviously lead to changes in the bacterial community composition not detected by FISH but by the cluster analysis of the DGGE banding patterns. In contrast to our study, stable seasonal DGGE patterns were found in a Swedish lake (Lindström 1998). In another study in various lakes (Lindström 2000), positive correlations between grazing by microzooplankton and chrysophytes and the composition of the bacterial community were found, suggesting that grazing was a significant factor controlling the bacterioplankton community composition.

The sequence analysis of the phylotypes excised from the DGGE bands revealed rather different relationships to identified isolates and phylotypes. Only few phylotypes of the $\alpha$ - and $\beta$-Proteobacteria were retrieved, whereas a much higher diversity of the Cytophaga/Flavobacteria and Actinobacteria was found. Sequence similarities of the phylotypes to known isolates ranged from $<90$ to $96.7 \%$, with lowest similarities in the Cytophaga/Flavobacteria, Actinobacteria and Holophaga/Acidobacterium cluster, and highest similarities within the $\alpha$ - and $\beta$-Proteobacteria and the Nitrospira phylum. Sequence similarities between our phylotypes of the $\alpha$ - and $\beta$-Proteobacteria were rather similar for known isolates and phylotypes. The phylotypes we retrieved from the Cytophaga/Flavobacteria, Holophaga/Acidobacterium and Actinobacteria cluster, however, were much closer related to phylotypes from other freshwater lakes than to known isolates, thus complementing other recent studies (Glöckner et al. 2000, Zwart et al. 2002). Phylotype LCo76 affiliated with the betaII cluster of Glöckner et al. (2000), unique to uncultured freshwater $\beta$-Proteobacteria. The next relatives of phylotype LCo74 of $\beta$-Proteobacteria, even though still fairly distantly related, were found to be important components of the bacterioplankton in a eutrophic lake (Höfle et al. 1999). Thirteen of our phylotypes were identified as Actinobacteria. Five of them appeared within typical bands present throughout the study period at $3 \mathrm{~m}$ depth, and thus were integral components of the bacterioplankton community in Lake Constance. The phylotypes LCo16, 17, 21, 22, 39, 72, and 78 of the high GC Actinobacteria fall into the hgcI cluster of Glöckner et al. (2000). This cluster is unique to uncultured freshwater bacteria, including phylotypes from various European and North American mountain lakes, and Lake Baikal (Hiorns et al. 1997, Zwart et al. 1998, 2002, Glöckner et al. 2000, Riemann \& Winding 2001), and thus presumably is a cluster of unique freshwater bacteria occurring worldwide. Interestingly, 5 of these phylotypes clustered particularly closely with those from Lake Baikal (Glöckner et al. 2000). The most closely related bacteria are Cellulomonas sp., Geodermatophilus sp., and 'Nostocoida limicola', of which the latter occurs in activated sludge with only a few known strains (Liu et al. 2000). The other 7 phylotypes of the high GC Actinobacteria are related to the deep-branching cluster of 'Microthrix parvicella'. This bacterium, even though only distantly related to the phylotypes we retrieved from Lake Constance, and of which only a few strains are known, also occurs in activated sludge (Blakall et al. 1995, 1996). Phylotypes of this cluster, related closely to our phylotypes, have also been detected in other freshwater lakes (Glöckner et al. 2000, Riemann \& Winding 2001). We did not detect Actinobacteria by FISH and thus are unable to estimate their quantitative significance. According to the results of Glöckner et al. (2000) using FISH, these bacteria appear to be of great importance in freshwater lakes but could only be detected by applying helper probes in FISH analyses. An experimental study showed that Actinobacteria are grazing resistant (Pernthaler et al. 2001). Therefore, and in agreement with our DGGE results, we assume that they are a prominent component of the bacterioplankton in Lake Constance and obviously in other lakes as well.

Our sequence analysis further identified phylotypes which affiliate with the novel Holophaga/Acidobacterium and the Nitrospira phylum, from which only 3 and 2 isolates are known, respectively (Watson et al. 1986, Ehrlich et al. 1995, Spring et al. 2000). Bacteria of the Holophaga/Acidobacterium group have recently been found in sediments of Lake Baikal and Lake Constance (Spring et al. 2000). Obviously, bacteria of this novel phylum are also present in the hypolimnion. The Nitrospira phylum has been found to comprise com- 
mon nitrite-oxidizers in waste-water treatment plants (Schramm et al. 1998, Okabe et al. 1999, Daims et al. 2000). Nitrospira phylotypes closely related to our phylotypes were recently retrieved from sediments of Green Bay, Lake Michigan, USA (Stein et al. 2001). As shown by the DGGE patterns, our phylotypes occurred at $50 \mathrm{~m}$ depth between August and October, and also in December at 3 and $20 \mathrm{~m}$. This finding suggests that nitrite-oxidation in Lake Constance during the stratified period in the hypolimnion and during winter mixing throughout the water column is mediated predominantly by Nitrospira-like bacteria, and further that nitrite-oxidation in lacustrine environments in general, not only in waste-water treatment plants, is mediated largely by bacteria of this phylum.

In summary, the FISH results show that $\beta$-Proteobacteria constituted the highest proportions of the identified bacterioplankton community followed by Cytophaga/Flavobacteria. The DGGE banding patterns and cluster analysis of the bacterioplankton community composition in Lake Constance revealed differences between the phytoplankton spring bloom and later in the season. The sequence analysis showed that in addition to $\alpha$ - and $\beta$-Proteobacteria and the Cytophaga/Flavobacteria members of the high GC Actinobacteria, the Nitrospira-phylum and members of the Holophaga/Acidobacterium group also occur regularly in the lake. Thus, the DGGE and sequence analysis complemented the FISH results by giving more detailed insights into the structure of the various bacterial groups detected by FISH, and by identifying phylotypes not targeted by the probes applied.

Acknowledgements. We very much appreciate constructive criticism by 3 anonymous reviewers on an earlier version of this manuscript. This work was supported by grant Si360/4-3 and the special collaborative program 'Cycling of Matter in Lake Constance' (SFB-248) from the Deutsche Forschungsgemeinschaft.

\section{LITERATURE CITED}

Alfreider A, Pernthaler J, Amann R, Sattler B, Glöckner FO, Wille A, Psenner R (1996) Community analysis of the bacterial assemblages in the winter cover and pelagic layers of a high mountain lake by in situ hybridization. Appl Environ Microbiol 62:2138-2144

Amann R, Krumholz L, Stahl DA (1990) Fluorescent-oligonucleotide probing of whole cells for determinative, phylogenetic, and environmental studies in microbiology. J Bacteriol 172:762-770

Amann RI, Ludwig W, Schleifer KH (1995) Phylogenetic identification and in situ detection of individual microbial cells without cultivation. Microbiol Rev 59:143-169

Blackall LL, Seviour EM, Cunningham MA, Sevious RJ, Hugenholtz P (1995) Microthrix parvicella is a novel, deep branching member of the actinomycetes subphylum. Syst
Appl Microbiol 17:513-518

Blackall LL, Stratton H, Bradford D, delDot T, Sjorup C, Seviour EM, Seviour RJ (1996) 'Candidatus Microthrix parvicella', a filamentous bacterium from activated sludge sewage treatment plants. Int J Syst Bacteriol 46:344-346

Brachvogel T, Schweitzer B, Simon M (2001) Dynamics and bacterial colonization of microaggregates in a large mesotrophic lake. Aquat Microb Ecol 26:23-35

Brümmer IHM, Fehr W, Wagner-Döbler I (2000) Biofilm community structure in polluted rivers: abundance of dominant phylogenetic groups over a complete annual cycle. Appl Environ Microbiol 66:3078-3082

Bunte C, Simon M (1999) Bacterioplankton turnover of dissolved free monosaccharides in a mesotrophic lake. Limnol Oceanogr 44:1862-1870

Cole JJ, Findlay S, Pace ML (1988) Bacterial production in fresh and saltwater ecosystems: a cross system overview. Mar Ecol Prog Ser 43:1-10

Cottrell M, Kirchman DL (2000) Natural assemblages of marine Proteobacteria and members of the Cytophagal Flavobacteria cluster consuming low- and high-molecular weight dissolved organic matter. Appl Environ Microbiol 66:1692-1697

Daims H, Nielsen PH, Nielsen JL, Juretschko S, Wagner M (2000) Novel Nitrospira-like bacteria as dominant nitriteoxidizers in biofilms from wastewater treatment plants: diversity and in situ physiology. FEMS Microbiol Ecol 33: 147-155

DeLong EF, Trent Taylor L, Marsh TL, Preston CM (1999) Visualization and enumeration of marine planktonic Archaea and Bacteria by using polyribonucleotide probes and fluorescence in situ hybridization. Appl Environ Microbiol 65:5554-5563

Don RH, Cox PT, Wainwright B, Baker K, Mattick JS (1991) 'Touchdown' PCR to circumvent spurious priming during gene amplification. Nucleic Acids Res 19:4008

Ehrlich S, Behrens D, Lebedeva E, Ludwig W, Bock E (1995) A new obligately chemolithoautotrophic nitrite-oxidizing bacterium, Nitrospira-moscoviensis sp. nov. and its phylogenetic relationship. Arch Microbiol 164:16-23

Eilers H, Pernthaler J, Glöckner FO, Amann R (2000) Culturability and in situ abundance of pelagic bacteria from the North Sea. Appl Environ Microbiol 66:3044-3051

Fuchs BM, Glöckner FO, Wulf J, Amann R (2000) Unlabeled helper oligonucleotides increase the in situ accessibility to 16S rRNA of fluorescently labeled oligonucleotide probes. Appl Environ Microbiol 66:3603-3607

Gaedke U (1998) The response of the pelagic food web to reoligotrophication of a large and deep lake (L. Constance): evidence for scale-dependent hierarchical patterns? Arch Hydrobiol Spec Issues Adv Limnol 53:317-333

Glöckner FO, Amann R, Alfreider A, Pernthaler J, Psenner R, Trebesius K, Schleifer KH (1996) An in situ hybridization protocol for detection and identification of planktonic bacteria. System Appl Microbiol 19:403-406

Glöckner FO, Fuchs BM, Amann R (1999) Bacterioplankton compositions of lakes and oceans: a first comparison based on fluorescence in situ hybridization. Appl Environ Microbiol 65:3721-3726

Glöckner FO, Zaichikov E, Belkova N, Denissova L, Pernthaler J, Pernthaler A, Amann R (2000) Comparative 16S rRNA analysis of lake bacterioplankton reveals globally distributed phylogenetic clusters including an abundant group of Actinobacteria. Appl Environ Microbiol 66: 5053-5056

Grossart HP, Simon M (1998) Bacterial colonization and microbial decomposition of limnetic organic aggregates 
(lake snow). Aquat Microb Ecol 15:127-140

Häse C, Gaedke U, Seifried A, Beese B, Tilzer MM (1998) Phytoplankton response to re-oligotrophication in large and deep Lake Constance: photosynthetic rates and chlorophyll concentrations. Arch Hydrobiol Spec Issues Adv Limnol 53:159-178

Hiorns WD, Methé BA, Nierzwicki-Bauer SA, Zehr JP (1997) Bacterial diversity in Adirondack Mountain lakes as revealed by $16 \mathrm{~S}$ rRNA gene sequences. Appl Environ Microbiol 63:2957-2960

Höfle MG, Haas H, Dominik K (1999) Seasonal dynamics of bacterioplankton community structure in a eutrophic lake as determined by 5S rRNA analysis. Appl Environ Microbiol 65:3164-3171

Hollibaugh JT, Wong PS, Murrell MC (2000) Similarity of particle-associated and free-living bacterial communities in northern San Francisco Bay, California. Aquat Microb Ecol 21:103-114

Jürgens K, Pernthaler J, Schalla S, Amann R (1999) Morphological and compositional changes in a planktonic bacterial community in response to enhanced protozoan grazing. Appl Environ Microbiol 65:1241-1250

Kemp PF, Lee S, LaRoch J (1993) Estimating the growth rate of slowly growing marine bacteria from RNA content. Appl Environ Microbiol 59:2594-2601

Kenzaka T, Yamaguchi N, Tani K, Nasu M (1998) rRNAtargeted fluorescent in situ hybridization of bacterial community structure in river water. Microbiology 144: 2085-2093

Knoll S, Zwisler W, Simon M (2001) Bacterial colonization of early stages of limnetic diatom microaggregates. Aquat Microb Ecol 25:141-150

Konopka A, Bercot T, Nakatsu C (1999) Bacterioplankton community diversity in a series of thermally stratified lakes. Microb Ecol 38:126-135

Lebaron P, Servais P, Trousselier M, Courties C and 6 others (1999) Changes in bacterial community structure in seawater mesocosms differing in their nutrient status. Aquat Microb Ecol 19:255-267

Lindström ES (1998) Bacterioplankton community composition in a boreal forest lake. FEMS Microbiol Ecol 27:163-174

Lindström ES (2000) Bacterioplankton community composition in five lakes differing in trophic status and humic content. Microb Ecol 40:104-113

Liu JR, Burrell P, Seviour EM, Soddell JA, Blackall LL, Seviour RJ (2000) The filamentous bacterial morphotype 'Nostocoida limicola' I contains at least two previously described genera in the low $\mathrm{G}+\mathrm{C}$ gram positive bacteria. Syst Appl Microbiol 23:528-534

Manz W, Amann R, Ludwig W, Wagner M, Schleifer KH (1992) Phylogenetic oligodeoxynucleotide probes for the major subclasses of Proteobacteria: problems and solutions. Syst Appl Microbiol 15:593-600

Manz W, Amann R, Ludwig W, Vancanneyt M, Schleifer KH (1996) Application of a suite of 16S rRNA-specific oligonucleotide probes designed to investigate bacteria of the phylum Cytophaga-Flavobacter-Bacteroides in the natural environment. Microbiology 142:1097-1106

Manz W, Wendt-Potthoff K, Neu TR, Szewzyk U, Lawrence JR (1999) Phylogenetic composition, spatial structure and dynamics of lotic bacterial biofilms investigated by fluorescent in situ hybridization and confocal laser scanning microscopy. Microb Ecol 37:225-237

Muyzer G, Hottenträger S, Teske A, Wawer C (1996) Denaturing gradient gel electrophoresis of PCR-amplified 16S rDNA - a new molecular approach to analyse the genetic diversity of mixed microbial communities. In: Akkermans
ADL, van Elsas JD, de Bruijn FJ (eds) Molecular microbial ecology manual, 2nd edn. Kluwer Academic Publishers, Dordrecht, p 1-23

Muyzer G, Brinkhoff T, Nübel U, Santegoeds C, Schäfer $H_{\text {, }}$ Wawer C (1998) Denaturing gradient gel electrophoresis (DGGE) in microbial ecology. In: Akkermans ADL, van Elsas JD, de Bruijn FJ (eds) Molecular microbial ecology manual, 3rd edn. Kluwer Academic Publishers, Dordrecht, p 1-27

Okabe S, Satoh H, Watanabe Y (1999) In situ analysis of nitrifying biofilms as determined by in situ hybridization and the use of microelectrodes. Appl Environ Microbiol 65: $3182-3191$

Pernthaler J, Glöckner FO, Unterholzner S, Alfreider A, Psenner R, Amann R (1998) Seasonal community and population dynamics of pelagic Bacteria and Archaea in a high mountain lake. Appl Environ Microbiol 64:4299-4306

Pernthaler J, Posch T, Šimek K, Vrba J and 5 others (2001) Predator-specific enrichment of Actinobacteria from a cosmopolitan freshwater clade in mixed continuous culture. Appl Environ Microbiol 67:2145-2155

Picard C, Ponsonnet C, Paget E, Nesme X, Simonet P (1992) Detection and enumeration of bacteria in soil by direct DNA extraction and polymerase chain reaction. Appl Environ Microbiol 58:2717-2722

Porter KG, Feig YS (1980) The use of DAPI for identifying and counting aquatic microflora. Limnol Oceanogr 25:943-948

Reichenbach H (1992) The order Cytophagales. In: Balows A, Trüper HG, Dworkin M, Harder W, Schleifer KH (eds) The Prokaryotes. Springer, New York, p 3631-3675

Riemann L, Winding A (2001) Community dynamics of freeliving and particle-associated bacterial assemblages during a freshwater phytoplankton bloom. Microb Ecol 42: $274-285$

Riemann L, Steward G, Azam F (2000) Dynamics of bacterial community composition and activity during a mesocosm diatom bloom. Appl Environ Microbiol 66:578-587

Rosenstock B, Simon M (2001) Sources and sinks of dissolved free amino acids and protein in a large and deep mesotrophic lake. Limnol Oceanogr 46:644-654

Schramm A, de Beer D, Wagner M, Amann R (1998) Identification and activities in situ of Nitrosospira and Nitrospira spp. as dominant populations in a nitrifying fluidized bed reactor. Appl Environ Microbiol 64:3480-3485

Schweitzer B, Huber I, Amann R, Ludwig W, Simon M (2001) Alpha- and beta-Proteobacteria control the consumption and release of amino acids on lake snow aggregates. Appl Environ Microbiol 67:623-645

Šimek K, Kojecká P, Nedoma J, Hartmann P, Vrba J (1999) Shifts in bacterial community composition associated with different microzooplankton size fractions in a eutrophic reservoir. Limnol Oceanogr 44:1643-1644

Šimek K, Pernthaler J, Weinbauer M, Hornák K, Dolan J, Nedoma J, Mašin M, Amann R (2001) Changes in bacterial community composition and dynamics and viral mortality rates associated with enhanced flagellate grazing in a mesoeutrophic reservoir. Appl Environ Microbiol 67: $2723-2733$

Simon M (1998) Bacterioplankton dynamics in a large mesotrophic lake: II. Concentrations and turnover of dissolved amino acids. Arch Hydrobiol 144:1-23

Simon M, Bunte C, Schulz M, Weiss M, Wünsch C (1998a) Bacterioplankton dynamics in Lake Constance (Bodensee): substrate utilization, growth control, and longterm trends. Arch Hydrobiol Spec Issues Adv Limnol 53: 195-221

Simon M, Tilzer MM, Müller H (1998b) Bacterioplankton 
dynamics in a large mesotrophic lake: I. Abundance, growth and relationships to phytoplankton growth. Arch Hydrobiol 143:385-407

Simon M, Glöckner FO, Amann R (1999) Different community structure and temperature optima of heterotrophic picoplankton in various regions of the Southern Ocean. Aquat Microb Ecol 18:275-284

Simon M, Grossart HP, Schweitzer B, Ploug H (2002) Microbial ecology of organic aggregates in aquatic environments. Aquat Microb Ecol 28:175-211

Southwick PL, Ernst LA, Tauriello EW, Parker SR, Mujumdar RB, Mujumdar SR, Clever HA, Waggoner AS (1990) Cyanine dye labeling reagents - carboxymethylindocyanine succinimidyl esters. Cytometry 11:418-430

Spring S, Schulze R, Overmann J, Schleifer KH (2000) Identification and characterization of ecologically significant prokaryotes in the sediment of freshwater lakes: molecular and cultivation studies. FEMS Microbiol Rev 24: $573-590$

Stein LY, La Duc MT, Grundl TJ, Nealson KH (2001) Bacterial and archaeal populations associated with freshwater ferromanganous micronodules and sediments. Environ Microbiol 3:10-18

Strunk O, Gross O, Reichel B, May M and 10 others (1998) ARB: a software environment for sequence data. Department of Microbiology, Technische Universität München, Munich (also available at http://www.arb-home.de)

Teske A, Wawer C, Muyzer G, Ramsing NB (1996) Distribution of sulfate-reducing bacteria in a stratified Fjord (Mariager Fjord, Denmark) as evaluated by most-proba-

Editorial responsibility: Karel Šimek,

České Budějovice, Czech Republic ble-number counts and denaturing gradient gel electrophoresis of PCR-amplified ribosomal DNA fragments. Appl Environ Microbiol 62:1405-1415

van Hannen E, Mooij W, van Agterveld MP, Gons HJ, Laanbroek HJ (1999) Detritus-dependent development of the microbial community in an experimental system: qualitative analysis by denaturing gradient gel electrophoresis. Appl Environ Microbiol 65:2478-2484

Wagner M, Amann R, Lemmer H, Schleifer KH (1993) Probing activated sludge with oligonucleotides specific for Proteobacteria: inadequacy of culture-dependent methods for describing microbial community structure. Appl Environ Microbiol 59:1520-1525

Watson SW, Bock E, Valois FW, Waterbury JB, Schlosser U (1986) Nitrospira-marina gen. nov., sp. nov.: a chemolithotophic nitrite-oxidizing bacterium. Arch Microbiol 144:1-7

Wawer C, Jetten MSM, Muyzer G (1997) Genetic diversity and expression of the (NiFe) hydrogenase large-subunit gene of Desulfovibrio spp. in environmental samples. Appl Environ Microbiol 63:4360-4369

Zwart G, Hiorns WD, Methé A, van Agterveld MP, Huismans R, Nold SC, Zehr JP, Laanbroek HJ (1998) Nearly identical 16S rRNA sequences recovered from lakes in North America and Europe indicate the existence of clades of globally distributed freshwater bacteria. Syst Appl Microbiol 21: 546-556

Zwart G, Crump BC, Kamst-van Agterveld MP, Hagen F, Han SK (2002) Typical freshwater bacteria: an analysis of available 16S rRNA gene sequences from plankton of lakes and rivers. Aquat Microb Ecol 28:141-155

Submitted: August 13, 2001; Accepted: December 19, 2002 Proofs received from author(s): March 11, 2003 